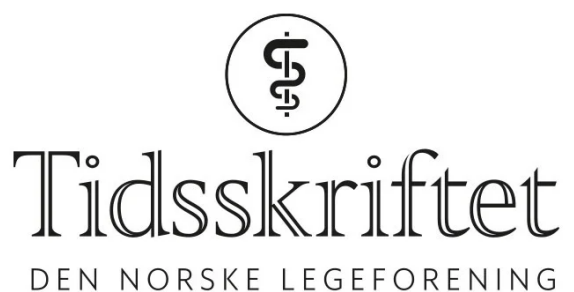

DEN NORSKE LEGEFORENING

\title{
«Eksperimentell» studie ble prisvinner
}

NYTT OM NAVN

LISA DAHLBAK JACOBSEN

lisa.dahlbak.jacobsen@tidskriftet.no

En studie på nalokson mot opioidoverdoser gitt som nesespray i stedet for intravenøs administrert, førte til kommersiell videreutvikling av preparatet - og prisen for «Beste originalartikkel». 


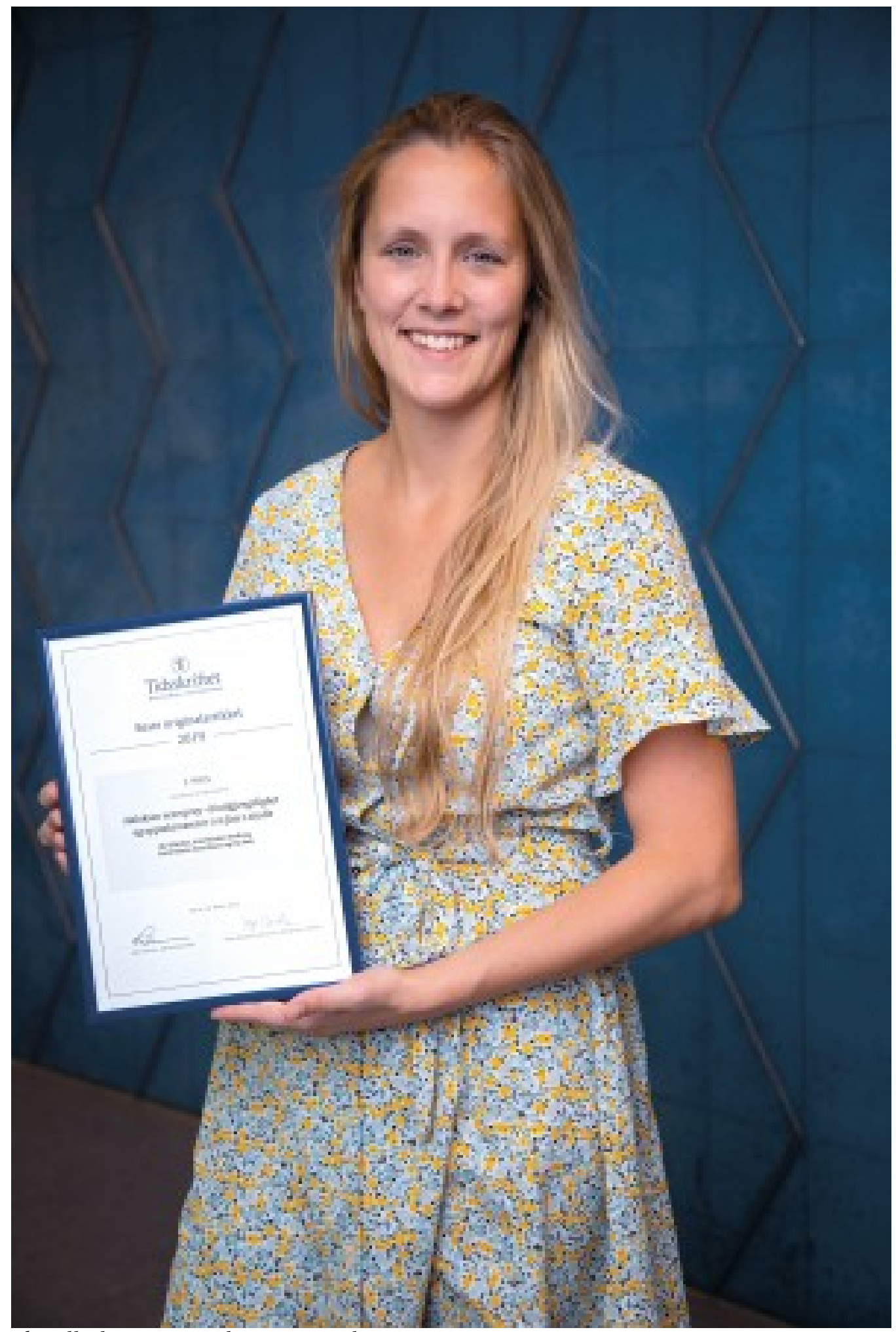

Ida Tylleskär. Foto: Karl Jørgen Marthinsen, NTNU

Naloksonnesespray - biotilgjengelighet og opptaksmønster i en fase 1-studie er kåret til «Beste originalartikkel 2019» i Tidsskrift for Den norske legeforening.

Førsteforfatter av vinnerartikkelen er Ida Tylleskär, lege og ph.d.-stipendiat ved Institutt for sirkulasjon og bildediagnostikk ved NTNU. Doktograden er levert, og disputasen ventes nå til høsten. At studien, og artikkelen ble prisvinner synes hun er veldig hyggelig.

- Studien som vinnerartikkelen baserer seg på, var et veldig morsomt prosjekt å jobbe med. Det at våre funn gjorde en forskjell for legemiddelutviklingen, og at nesesprayen nå er tilgjengelig i apotek og beskrevet i Felleskatalogen er veldig givende. Det var den aller første studien på dette, og jeg har vært med helt fra begynnelsen på prosjektet. Det var fint å kunne fortelle om det i Tidsskriftet, sier Tylleskär. 
Hun forteller om et godt samarbeid med redaksjonen i Tidsskriftet, men legger til:

- Det er litt morsomt - sett i ettertid - at vi faktisk i første omgang fikk tilbakemelding om at vi kanskje burde sende inn artikkelen som en kommentar i stedet for en originalartikkel. Men artikkelen ble veldig bra, og vi hadde en god prosess.

\section{«Koronakåring»}

Vinneren av «Beste originalartikkel 2019» og «Årets fagvurderer» ble kåret rett før sommeren. Normalt sett benytter Tidsskriftet det årlige «Møte for faglige medarbeidere» til utdeling av premien. I pandemiens år ble hele møtet avlyst, og prisvinnerne fikk blomster og diplom tilsendt i posten.

I Tidsskriftet foregår arbeidet med å velge ut foregående års beste artikkel på følgende måte:

- Vi starter med en preutvelgelse blant alle fjorårets artikler - $\mathrm{i}$ år blant alle innsendte originalartikler. Altså samler vi en topp 10-liste basert på fornuftig redaksjonell prosess. Det er fordi mange manuser får mye redaksjonell hjelp av oss. De ekskluderer vi i denne første utvelgelsen, forklarer Inge Rasmus Groote, juryformann og medisinsk redaktør i Tidsskriftet.

Han bekrefter at alle 10 artikler i topplisten hadde en upåklagelig redaksjonell prosess.

Blant Tidsskriftets faste medarbeidere ble det samlet en jury, og jurymedlemmene fikk i oppgave å plukke en topp 3-liste.

- Det var en soleklar vinner i år. Alle i juryen hadde originalartikkelen «Naloksonnesespray - biotilgjengelighet og opptaksmønster i en fase 1-studie» på sin toppliste.

Groote forteller at artikkelen skiller seg ut i mengden ved at det på en måte er en eksperimentell studie.

- Det er ikke så ofte den type artikler blir publisert i Tidsskriftet. Den beskriver et biologisk fenomen, men med høy relevans for norsk medisin. Det er beundringsverdig at noen gjør slikt, og studien er godt gjennomført. Presentasjonen er litt annerledes, og artikkelen er morsom å lese.

I år valgte Tidsskriftet å premiere årets beste originalartikkel. Tidligere har det oftest vært beste oversiktsartikkel som har fått utmerkelser. Begrunnelsen er ifølge Groote at det har vært dårlig tilfang av oversiktsartikler de siste årene, og at man derfor valgte å heller se på originalartiklene.

\section{Årets fagvurderer}

Også årets fagvurderer ble, tradisjonen tro, kåret for foregående år. Juryen er stolte over å utnevne Johan Ræder til «Årets fagvurderer 2019». 


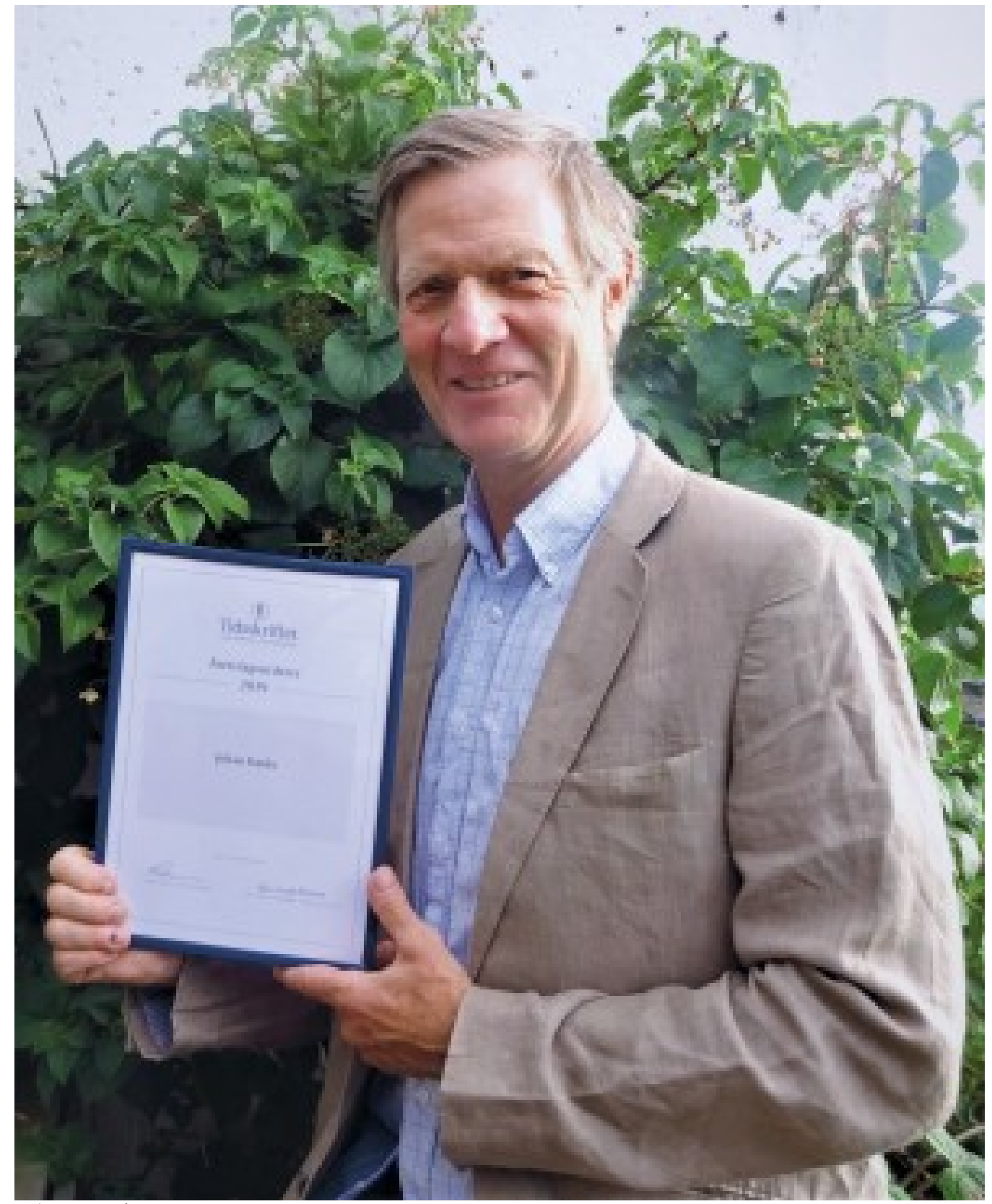

Johan Ræder. Foto: Privat

- Han har i en årrekke bidratt på en solid måte som faglig medarbeider i anestesiologi. Han er grundig, streng, men samtidig konstruktiv i tilbakemeldingen til forfatterne.

Vurderingene er godt strukturerte, gjennomarbeidede og til stor hjelp i det redaksjonelle arbeidet, forteller Siri Lunde Strømme, vitenskapelig redaktør i Tidsskriftet.

Selv sier Ræder følgende:

- Det er absolutt veldig inspirerende og hyggelig å få en slik pris. Selv om de fleste av oss fagfellevurderere holder foredrag i utlandet og skriver i de store internasjonale tidsskriftene, er det ekstra varmende med anerkjennelse fra det hjemlige miljøet, som også er faglig mye bredere enn når vi eventuelt høster laubær internasjonalt.

Han forklarer at hans egen tilnærming som fagvurderer er at han forsøker være ydmyk overfor alle de tre forskjellige aktørerene, altså leserne, forfatterne og redaksjonen.

Publisert: 12. oktober 2020. Tidsskr Nor Legeforen. DOI: 10.4045/tidsskr.20.0736

(C) Tidsskrift for Den norske legeforening 2023. Lastet ned fra tidsskriftet.no 26. april 2023. 